\title{
Changes in Terpene Content in Milk from Pasture-Fed Cows
}

\author{
G. Tornambé, ${ }^{*} \dagger^{1}$ A. Cornu, ${ }^{\star} \ddagger$ P. Pradel,§ N. Kondjoyan,‡ A. P. Carnat,\# M. Petit, ${ }^{\star}$ and B. Martin ${ }^{\star}$ \\ *Unité de Recherches sur les Herbivores, INRA, Theix, France \\ †Dipartimento S.En.Fi.Mi.Zo, Facoltà di Agraria, Universita degli Studi di Palermo, Palermo, Italy \\ ¥Unité Qualité des Produits Animaux-Typicité Aromatique et Authentification, INRA Theix, France \\ §Unité Expérimentale de Marcenat, INRA, Marcenat, France \\ \#Laboratoire de Phytopharmacognosie, Faculté de Pharmacie, Clermont-Ferrand, France
}

\section{ABSTRACT}

Changes of terpene content in milk from cows grazing natural diversified upland pasture were examined in this observational trial. A homogeneous plot divided into 2 subplots was used from May 31 to July 1, 2003 (first growth) and again from October 1 to October 7, 2003 (vegetative regrowth). Each subplot was grazed by 6 dairy cows in 2 ways: strip grazing (SG), with new allocations of pasture strips at 2-d intervals, and paddock grazing (PG). The PG subplot was divided into 3 paddocks and the cows were moved to a new paddock on June 13 and June 24, 2003. Milk from the 6 cows was collected twice a week, pooled, and used for terpene analyses by dynamic headspace gas chromatographymass spectrometry system. Twenty mono- and 23 sesquiterpenes desorbing from the milk fat were separated. The most abundant monoterpenes were $\beta$-pinene, $\alpha$-pinene, $\gamma$-terpinene, limonene, $\alpha$-tujene, terpinolene, and $\alpha$-phellandrene. The most abundant sesquiterpenes were $\beta$-caryophyllene, $\alpha$-copaene, $\beta$-cedrene, transmuurola-4-(14)-5-diene, $\beta$-bisabolene, and $\delta$-cadinene. Both mono- and sesquiterpenes in SG milk increased across time with an 8-fold increase in total terpenes in milk from the beginning to the end of June. In parallel, dicotyledons, including the main terpenerich plants, increased from 17 to $31 \%$ of total biomass of the vegetation and the development of Dactylis glomerata progressed from boot to ripening stage. The terpenes in PG milk were equivalent to those in SG milk for the first paddock at the beginning of June and remained constant or doubled for the sum of mono- and sesquiterpenes, respectively. The lower variability of the PG milk terpene content could be related to the opportunity that PG cows had to choose ingested herbage, whereas the SG cows had limited choice within the smaller allocated pasture strips. Milk from cows grazing regrowth pastures in October contained low levels of terpenes, and

Received July 26, 2005

Accepted January 17, 2006.

${ }^{1}$ Corresponding author: gtornambe@unipa.it values were similar for PG and SG milks. Change in the sum of monoterpenes is representative of changes for most monoterpenes (except for limonene) and, conversely, the change in the sum of sesquiterpenes mainly reflected changes in $\beta$-caryophyllene and $\alpha$-copaene. In addition to effects of botanical composition of pasture, it appears that terpene content in milk may vary according to factors linked to grazing management that need more intensive study. Nevertheless, current results raise questions about the precision of terpenes as feed tracers.

Key words: pasture development, grazing management, milk terpene, upland pasture

\section{INTRODUCTION}

Terpenes are a group of plant-specific compounds that originate almost exclusively from the plant's secondary metabolism. The terpenes considered here are mono- and sesquiterpenes (10 and 15 carbon atoms, respectively). They are the main components of essential oils, and when concentrated, they have many recognized aromatic properties. These compounds are involved in plant pollination, in plant resistance to predation (repellents), and infection (antimicrobial agents; Deans et al., 1978; Hammer et al., 1999; Burt, 2004). They abound in certain species, particularly dicotyledons such as the Apiaceae, Lamiaceae, or Asteraceae families, whereas the terpene content is low in most Poaceae. In forages, the terpene content is mainly governed by its botanical composition: Poaceae-based forages are terpene-poor, whereas upland diversified pasture forages, which include many dicotyledons, are terpene-rich (Mariaca et al., 1997; Bugaud et al., 2000, 2001). Because terpene production is regulated by physiological and metabolic factors that are highly susceptible to modulation through environmental conditions (Chalchat and Michet, 1997; Sangwan et al., 2001), variations may also occur within plants according to their maturity stage (Cornu et al., 2001).

These compounds have been detected and identified in dairy products for decades (Dumont and Adda, 1978) and recently confirmed (Viallon et al., 2000). Dairy 
product terpenes have recently attracted interest both for their possible impact on cheese sensory properties (Bugaud et al., 2002; Carpino et al., 2004; Coulon et al., 2004) and as potential markers in milk and cheese of the presence of diversified forages in dairy cows' diet (Viallon et al., 1999; Bendall, 2001; Martin et al., 2005), especially for mountain cheeses (Moio et al., 1996; Fernandez et al., 2003; Zeppa et al., 2004). Interest in terpenes as biomarkers for dairy products and meat from small ruminants has been recently reviewed by Prache et al. (2005). Many authors have shown that these compounds occur in greater amounts in dairy products from the milk of cows fed on diversified upland grassland than in those from cows fed on less broadly diversified or monospecific meadows (Dumont et al., 1981; Bosset et al., 1994; Cornu et al., 2002a). Other authors attribute the presence of terpenes in cheese to the activity of Penicillium caseifulvum and of Penicillium camemberti fungus (Larsen, 1999). Nevertheless, very wide variability in the terpene content of bulk milk collected in restricted areas through the grazing season has been reported (Fernandez et al., 2003). It is likely that such variability is linked partly to seasonal changes in the botanical composition of the meadows grazed by cows and also to factors linked to the grazing management of the cows (development stage of the plants, grazing technique, etc.). To use terpenes as dietary markers in dairy products, there is a need to account for more of the unexplained variability. The aim of this trial was to give an overview of the possible changes through the grazing season of the milk terpene content of cows fed a single natural diversified upland pasture grazed in different ways (strip or paddock grazing).

\section{MATERIALS AND METHODS}

\section{Grassland}

The plot used in this experiment was a 3.4-ha diversified upland pasture (1,100 m elevation) on the Marcenat INRA experimental farm located in the Cantal department (France). Fifteen percent of the total surface area of the meadow was flat; the main part was a homogeneous slight slope of $9^{\circ}$. This grassland, growing on a volcanic soil, had been extensively grazed until the 1970s and fertilized with manures. The botanical composition of the pasture was determined on August 1, 2003 , by 2 linear surveys on a $25-\mathrm{m}$ transect by a point quadrat method. The plants in contact with a vertical stick were recorded at 50 points, located $0.5 \mathrm{~m}$ apart on the transect. At each point, 0,1 , or $>1$ species could have been hit. Relative cover of a species was calculated as the ratio of the number of recorded presences for a given species to the sum of presence for all species and expressed as a percentage. The mean botanical composition of the meadow is the average of the 2 surveys.

This plot was exploited from May 31 to July 1, 2003 (first growth), and again from October 1 to October 7, 2003 (regrowth). It was divided in 2 subplots (1.4 and $2.0 \mathrm{ha}$ ) in which the botanical composition was as similar as possible. Each subplot was grazed by 6 dairy cows in one of the following ways: either strip grazing (SG) or paddock grazing (PG) in the 1.4- and 2.0-ha subplots respectively. To have 2 contrasting situations in which cows had limited or important choice capacity, the total surface allocated to the cows was larger for the PG than for the SG group. In the SG subplot, the strip limits, in the form of front and rear electrified wires, were moved forward every $2 \mathrm{~d}$. The PG subplot was divided into 3 paddocks of 0.67 ha each and the cows were moved to a new paddock on June 13 and June 24, 2003, after the morning milkings.

Pasture sampling and measurements were taken twice a week in each paddock and before PG cows entered a new paddock. Pasture height was the average of 100 random measurements carried out using an electronic sliding grass-meter (Herbometre, Arvalis, Paris, France). The residual pasture height was also measured after grazing. To estimate the standing biomass, 5 lines $(10 \mathrm{~cm} \times 200 \mathrm{~cm})$ were cut at $2 \mathrm{~cm}$ above ground level with electric shears. The samples corresponding to 3 lines were weighed before and after oven drying $\left(103^{\circ} \mathrm{C}\right.$ for $\left.24 \mathrm{~h}\right)$. In addition, 1 sample (corresponding to 1 line) was separated into monocotyledons and dicotyledons and oven-dried at $103^{\circ} \mathrm{C}$ for $24 \mathrm{~h}$, and another sample was analyzed for DM, crude fiber, and CP; OM digestibility was estimated according to Andrieu et al. (1981). Chemical analyses were expressed on a DM $\left(105^{\circ} \mathrm{C}\right)$ basis. Twice during the trial (at the beginning and at the end of trial), an additional pasture sample was collected and the plant material corresponding to heights 0 to $10 \mathrm{~cm}, 10$ to $22 \mathrm{~cm}$, and $>22 \mathrm{~cm}$ from the ground was separated. In each horizon, the mono- and dicotyledons were separated and oven-dried $\left(103^{\circ} \mathrm{C}\right.$ for $24 \mathrm{~h}$ ). In addition, development stages of 3 key plants, Dactylis glomerata, Meum athamanticum, and Achillea millefolium, were noted once a week.

\section{Animals and Diet}

Ten Montbéliarde and 2 Tarentaise cows (110 and 90 DIM, respectively, at the start of the experiment) yielding 26 and $16 \mathrm{~kg} / \mathrm{d}$, respectively, were used in this experiment. They were divided into 2 equivalent groups of 5 Montbéliarde and 1 Tarentaise cows based on milk yield and stage of lactation. During the first experimental period (early June), the cows received a supplement of commercial mixture [made of wheat (37.3\%), molas- 
ses $(2.5 \%)$, bran $(22.6 \%)$, wheat gluten $(14.4 \%)$, sunflower cake $(5.4 \%)$, rapeseed cake $(4.6 \%)$, cereal byproducts $(10.0 \%)$ and carbonate, minerals, and vitamins (3.2\%)] given individually after the morning milking. The quantity of concentrates was constant over the experimental period and determined according to milk yield at the beginning of this period: $5.5 \mathrm{~kg}$ of DM/d for daily milk yields $>20 \mathrm{~kg}, 2.8 \mathrm{~kg}$ of DM/d for milk yields of 15 to $20 \mathrm{~kg} / \mathrm{d}$, and no concentrate for cows milking $<15 \mathrm{~kg} / \mathrm{d}$. Between July and October, the animals in the 2 groups grazed together and were given concentrates according to their individual production measured at the end of June. In early October, the animals only fed on grazed pasture. Individual milk production was measured at each milking.

\section{Milk Sampling and Analyses}

Individual milk (70 $\mathrm{mL})$ and pooled milk from the 6 cows in each group (180 mL) corresponding to $24-\mathrm{h}$ production was sampled twice a week. All the samples were composed of a ratio of 60:40 for morning and evening milkings. Individual milk samples were used for determination of fat and protein content (infrared method, Milkoscan 4000, Foss System, Hillerød, Denmark) and SCC (Fossomatic 5000, Foss System). The 180 -mL pooled milk samples were stored at $-20^{\circ} \mathrm{C}$ until analyses for terpene. Milk lipids were extracted by a method adapted from Viallon et al. (2000) to perform a single centrifugation step. The frozen milk samples were left overnight to thaw at $20^{\circ} \mathrm{C}$. About $40 \mathrm{~g}$ of the creamy upper layer was weighed in a $40-\mathrm{mL}$ screw cap polyallomer bottle (357003, Beckman Inc., Palo Alto, $\mathrm{CA}$ ), and centrifuged for $2 \mathrm{~h}$ at $75,000 \times g$ at $25^{\circ} \mathrm{C}$ in an Avanti J-301 centrifuge (Beckman). The supernatant liquid fat phases (clear yellow) were taken up using a Pasteur pipette and stored at $-20^{\circ} \mathrm{C}$.

Volatile compounds were extracted by the dynamic headspace method using a Tekmar LSC 2000 apparatus (Tekmar, Cincinnati, OH). The fat $(0.2 \mathrm{~g})$ was deposited on $0.2 \mathrm{~g}$ of glass wool placed in a glass extraction cartridge (diameter: $28 \mathrm{~mm}$, height: $70 \mathrm{~mm}$ ). The extraction conditions were: purge $30 \mathrm{~min}$ at $110^{\circ} \mathrm{C}$ with helium at $47 \mathrm{~mL} / \mathrm{min}$, trap on Tenax at $30^{\circ} \mathrm{C}$, preheating of the trap at $175^{\circ} \mathrm{C}$, desorption at $180^{\circ} \mathrm{C}, 5 \mathrm{~min}$, transfer line temperature: $200^{\circ} \mathrm{C}$, cryofocusing at $-150^{\circ} \mathrm{C}$ in the chromatograph injection port, injection by heating $2 \mathrm{~min}$ at $225^{\circ} \mathrm{C}$, gas chromatograph oven temperature: $40^{\circ} \mathrm{C}$, and baking of trap before next injection $10 \mathrm{~min}$ at $180^{\circ} \mathrm{C}$.

Volatile compounds were separated by gas chromatography using a Hewlett-Packard 5890 chromatograph (Hewlett-Packard France, Les Ulis, France). The separation conditions were: capillary column $(60 \mathrm{~m} \times$
$0.32 \mathrm{~mm}$; Supelco, CH-1196 Gland, Switzerland); stationary phase SPB-5 $(1 \mu \mathrm{m})$; carrier gas: helium $(1 \mathrm{~mL} /$ min); oven program: $5 \mathrm{~min}$ at $40^{\circ} \mathrm{C}$, increase to $230^{\circ} \mathrm{C}$ at $3^{\circ} \mathrm{C} / \mathrm{min}$, and then $2 \mathrm{~min}$ at $230^{\circ} \mathrm{C}$. Detection, semiquantification, and identification were performed using an HP5971S electron impact $(70 \mathrm{eV})$ mass spectrometer (Hewlett-Packard). The terpenoids were detected in the "selected ion mode" by monitoring their characteristic ions at $m / z=93,136,161$, and 204 (Fernandez et al., 2003). Semiquantification was performed by integrating the "93" ion peaks between $25 \mathrm{~min}$ and $50 \mathrm{~min}$ for monoterpenes and the " 161 " ion peaks between 50 min and 70 min for sesquiterpenes, using the MS Chemstation software (Hewlett-Packard). No correction was applied for coelution or mass fragment ratios. The results were expressed in arbitrary area units (aau). A sample chosen among the richest in terpenes was analyzed again, monitoring ions between $\mathrm{m} / \mathrm{z} 33$ and 230 . Identification of terpenoids was proposed based on mass spectra and experimental retention indices, by comparison with those found in published databases (Kondjoyan and Berdagué, 1996; NIST/EPA/NIH, 1996; Adams, 2001).

\section{Data Analyses}

For data description, 4 periods were defined: the first 3 periods (I, II, and III) were those corresponding to the time spent in June on the 3 paddocks grazed by the PG group, and the fourth period (named ' $R$ ' for regrowth) was the early October experimental period. During periods I, II, III, and R, separate analyses for terpenes in milk were $4,3,2$, and 2 , respectively, for each group of cows. Data reported in the tables are mean values and standard error deviation corresponding to each period and grazing management. For data obtained in periods I, II, and III, we also calculated the linear correlations between the sampling date (days spent on the plot, which correspond to a growth stage evolution) and content of terpenes in milk. The GLM procedure of SAS software (SAS Institute, 2000) was used, including in the model the type of grazing management ( $\mathrm{SG}$ or $\mathrm{PG}$ ), the date, and the date nested in the type of management (the interaction). When the effect of the interaction was significant $(P<0.05)$, the slopes of the correlation between date and terpene contents were reported individually for SG and PG groups. When the effect of the interaction was not significant, the interaction was removed from the model, and the global slope of the correlation between date and terpene contents was reported.

The individual cow measurements for milk yield, protein, and fat content were averaged by cow for each period. These data were analyzed with repeated mea- 
Table 1. Species making up more than $1 \%$ of the total number of plants in the upland pasture

\begin{tabular}{lr}
\hline & $\%$ \\
\hline Poaceae (n =14 total) & 44 \\
Festuca rubra & 14.5 \\
Agrostis capillaris & 9.5 \\
Carex caryophyllea & 6.2 \\
Festuca nigrescens & 4.8 \\
Anthoxanthum odoratum & 2.5 \\
Deschampsia flexuosa & 1.5 \\
Cynosurus cristatus & 1.3 \\
Briza media & 1.3 \\
Avenula pubescens & 1.2 \\
Dicotyledons (n = 32 total) & 56 \\
Hieracium pilosella & 7.8 \\
Thymus pulegioides & 5.5 \\
Gentiana lutea & 5.0 \\
Stachys officinalis & 4.8 \\
Achillea millefolium & 4.2 \\
Helianthemum nummularium & 3.2 \\
Galium verum & 3.2 \\
Meum athamanticum & 2.7 \\
Scabiosa columbaria & 2.5 \\
Potentilla tabernaemontani & 2.5 \\
Trifolium repens & 2.0 \\
Chamaespartium sagittale & 1.8 \\
Plantago lanceolata & 1.7 \\
Lotus corniculatus & 1.3 \\
Veronica chamaedrys & 1.0 \\
Pimpinella saxifraga & 1.0 \\
\hline
\end{tabular}

sures using the Mixed procedure of SAS. The statistical model included the type of grazing management (SG or $\mathrm{PG}$ ), the period (date of beginning of each period), and the interaction. Cow was the random effect.

\section{RESULTS}

\section{Paddock and Vegetation}

Forty-six plant species were identified in the plot: 14 Poaceae and 32 dicotyledons. Their relative contribution to the total number of plants was 44 and $56 \%$, respectively. The main species identified and their relative contributions are listed in Table 1. At entry into the plot, D. glomerata was at the boot stage; on July 1 , it was at the mature stage. During June, the development stage of $M$. athamanticum evolved from flowering to the seed formation stage and to the first regrowth. Achillea millefolium developed later than $M$. athamanticum; it was leafy at entry into the grassland and the proportion of flowers increased during June (Table 2). On average for both SG and PG paddocks, on June 2 the biomass and pasture height were $2.3 \mathrm{t}$ of $\mathrm{DM} / \mathrm{ha}$ and $148 \mathrm{~mm}$, respectively. From June 13 until the end of June, the biomass and pasture height were slightly lower (Table 3). From periods I to III, the proportion of dicotyledon plants increased from 17 to $31 \%$ of the DM weight of the pasture samples. In parallel, $\mathrm{CP}$ and $\mathrm{OM}$ digestibility decreased by 19 and 9\%, respectively. The pasture height after grazing ranged between 68 and $82 \mathrm{~mm}$ in SG and 79 and 105 in PG. During the regrowth period (October), the biomass and pasture height were $0.8 \mathrm{t}$ of DM/ha and $77 \mathrm{~mm}$, respectively. The proportion of dicotyledons was $22 \%$ of the DM weight of the pasture samples.

\section{Milk Production and Characteristics}

From the beginning to the end of June, milk yield decreased by 3.9 and $3.4 \mathrm{~kg} / \mathrm{cow}$ for SG and PG, respectively (Table 3). Milk protein content decreased on average by $1.8 \mathrm{~g} / \mathrm{kg}$ between periods I and II, and then remained constant until the end of June for both groups. Milk fat content increased across time for the SG group, whereas in the PG group, milk fat decreased from the first to the second paddock, and increased in the third. In October, with advancing stage of lactation and grazing on regrowth pastures, milk yield was lower, and fat and protein content were higher than in June.

\section{Terpenes}

Integrating the $\mathrm{m} / \mathrm{z} 93$ ion in the first part of the chromatogram and the $\mathrm{m} / \mathrm{z} 161$ ion in the second part gave rough estimates of monoterpene and sesquiterpene contents that allowed comparison of milks. Conse-

Table 2. Development stages of 3 key plants at the different sampling dates

\begin{tabular}{|c|c|c|c|c|c|}
\hline & \multicolumn{5}{|c|}{ Sampling date } \\
\hline & June 3 & June 10 & June 16 & June 24 & July 1 \\
\hline Dactylis glomerata ${ }^{1}$ & Boot stage & Heading & Anthesis & End of anthesis & Ripening stage \\
\hline Meum athamanticum & $\begin{array}{l}\text { Complete } \\
\text { flowering }\end{array}$ & $\begin{array}{l}\text { Beginning of } \\
\text { Seed formation } \\
\text { stage }\end{array}$ & $\begin{array}{l}\text { Seed formation } \\
\text { stage }\end{array}$ & $\begin{array}{l}\text { Seed formation } \\
\text { stage and regrowth }\end{array}$ & $\begin{array}{l}\text { Seed formation } \\
\text { stage and } \\
\text { leafy regrowth }\end{array}$ \\
\hline
\end{tabular}

\footnotetext{
${ }^{1}$ Although Dactylis glomerata represented $<1 \%$ of the pasture species in the study, it was used to give an overview of the maturity of
} grass species because it is common in many pasture communities. 
Table 3. Grassland characteristics and milk yield and composition

\begin{tabular}{|c|c|c|c|c|c|c|c|c|}
\hline & \multicolumn{8}{|c|}{ Period $^{1}$ and grazing management ${ }^{2}$} \\
\hline & \multicolumn{2}{|c|}{$\mathrm{I}$} & \multicolumn{2}{|c|}{ II } & \multicolumn{2}{|c|}{ III } & \multicolumn{2}{|c|}{$\mathrm{R}$} \\
\hline & SG & PG & SG & PG & SG & PG & SG & PG \\
\hline $\mathrm{CP}, \mathrm{g} / \mathrm{kg}$ of $\mathrm{DM}$ & \multicolumn{2}{|c|}{138} & \multicolumn{2}{|c|}{119} & \multicolumn{2}{|c|}{113} & \multicolumn{2}{|c|}{171} \\
\hline Crude fiber, $\mathrm{g} / \mathrm{kg}$ of DM & \multicolumn{2}{|c|}{297} & \multicolumn{2}{|c|}{304} & \multicolumn{2}{|c|}{288} & \multicolumn{2}{|c|}{250} \\
\hline OM digestibility, \% & \multicolumn{2}{|c|}{71} & \multicolumn{2}{|c|}{66} & \multicolumn{2}{|c|}{65} & \multicolumn{2}{|c|}{75} \\
\hline Offered herbage height, $\mathrm{mm}$ & \multicolumn{2}{|c|}{148} & \multicolumn{2}{|c|}{142} & \multicolumn{2}{|c|}{112} & \multicolumn{2}{|c|}{77} \\
\hline Herbage DM content, \% & \multicolumn{2}{|c|}{23} & \multicolumn{2}{|c|}{30} & \multicolumn{2}{|c|}{38} & \multicolumn{2}{|c|}{34} \\
\hline Herbage DM content, \% & \multirow{2}{*}{\multicolumn{2}{|c|}{$\begin{array}{c}2.3 \\
17\end{array}$}} & \multirow{2}{*}{\multicolumn{2}{|c|}{$\begin{array}{l}1.9 \\
21\end{array}$}} & \multirow{2}{*}{\multicolumn{2}{|c|}{$\begin{array}{l}1.8 \\
31\end{array}$}} & \multirow{2}{*}{\multicolumn{2}{|c|}{0.8}} \\
\hline Dicotyledons/biomass, \% of DM & & & & & & & & \\
\hline Stocking rate, $\mathrm{m}^{2} /$ cow per $\mathrm{d}$ & 75 & 93 & 75 & 102 & 75 & 140 & 150 & 186 \\
\hline Residual herbage height, mm & 82 & 98 & 75 & 79 & 68 & 105 & 70 & 73 \\
\hline Milk yield, kg/d per cow & 22.0 & 22.4 & 19.0 & 19.8 & 17.1 & 18.0 & 12.1 & 12.8 \\
\hline Fat, $\mathrm{g} / \mathrm{kg}$ & 33.7 & 36.8 & 35.3 & 34.8 & 36.4 & 38.8 & 43.7 & 46.7 \\
\hline Protein, g/kg & 32.4 & 31.7 & 30.6 & 30.3 & 30.9 & 30.0 & 38.8 & 37.2 \\
\hline $\mathrm{SCC}, \times 1,000 / \mathrm{mL}$ & 83 & 102 & 90 & 37 & 157 & 195 & 195 & 112 \\
\hline
\end{tabular}

${ }^{1} \mathrm{I}=$ from May 31 to June $13(13 \mathrm{~d}) ; \mathrm{II}=$ from June 13 to June $24(11 \mathrm{~d}) ; \mathrm{III}=$ from June 24 to July 1 (7 d); $R=$ regrowth period: from October 1 to October 6 ( $5 \mathrm{~d})$.

${ }^{2} \mathrm{SG}=$ Strip grazing; $\mathrm{PG}=$ paddock grazing.

quent changes in milk terpene profiles were observed during the course of the experiment (Figures 1 and 2). Both mono- and sesquiterpenes in SG milks increased continuously with time and were multiplied by 5 and 1.5 between periods I and III for mono- and sesquiterpenes, respectively (Tables 4 and 5). The terpenes in PG milks followed a different pattern, with no global increase for monoterpenes and a slight increase for sesquiterpenes. Mono- and sesquiterpene contents of PG milk at entry to the first and second paddocks were similar to those of the corresponding SG milks. By the end of June, monoterpenes were about 4 times greater and sesqui-

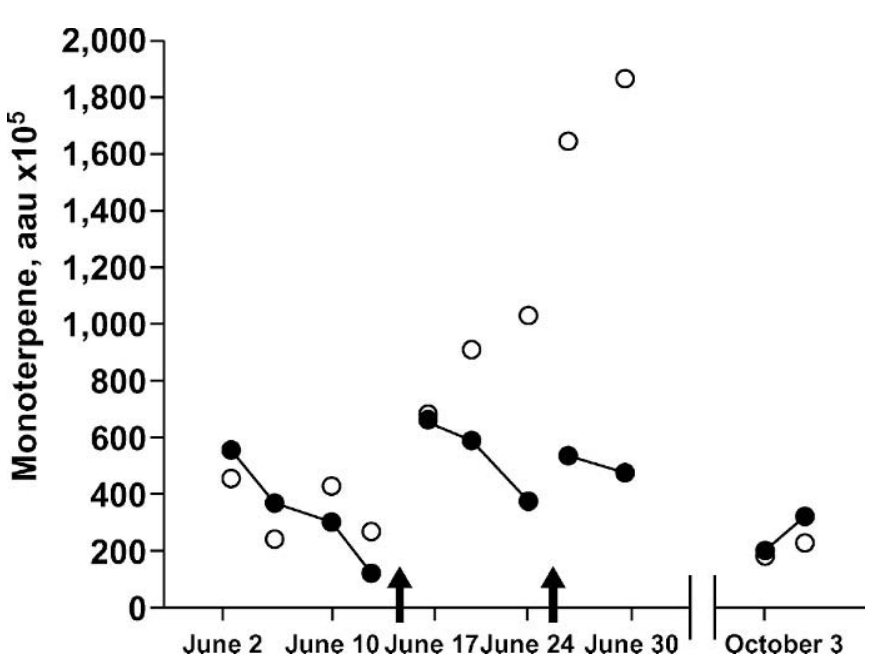

Figure 1. Milk monoterpene content evolution according to the sampling dates for strip grazing $(\bigcirc)$ or paddock grazing $(\bullet)$ cows. $\uparrow=$ paddock changing for PG cows; aau = arbitrary area units. terpenes were more than double in milk from SG cows compared with milk from PG cows. Milk mono- and sesquiterpene content sharply increased at entry to each paddock, and then slowly decreased (Figures 1 and 2). This decrease was not so clearly observed for the third paddock, but only 2 samples had been collected from it. The milks from regrowth pasture in October contained low levels of terpenes, and values were similar, on average, for PG and SG milks.

Forty-three terpenes were found in the milks. Identification was proposed for 18 of the 20 monoterpenes

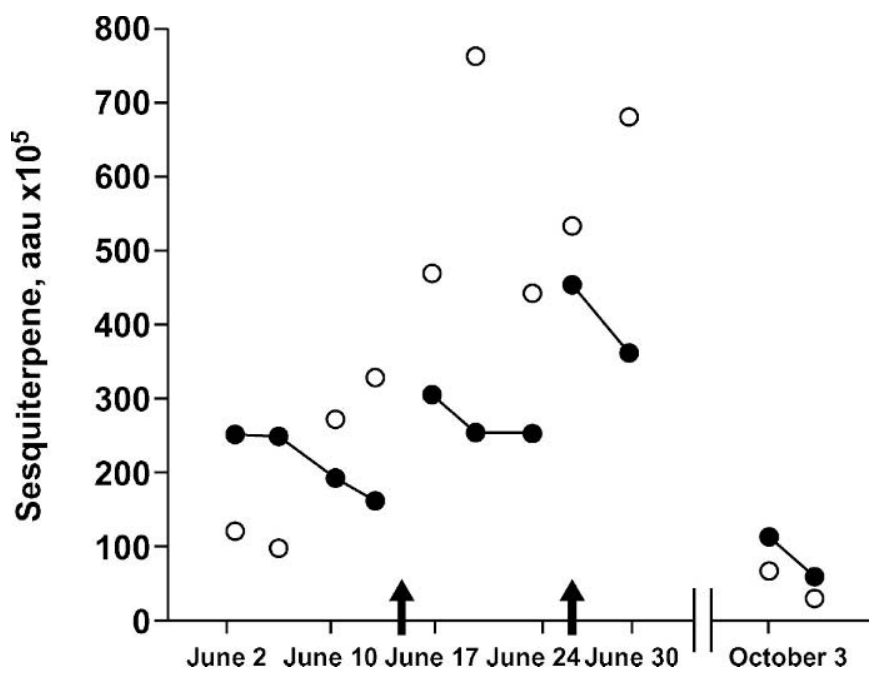

Figure 2. Milk sesquiterpene content evolution according to the sampling dates for strip grazing $(\bigcirc)$ or paddock grazing $(\bullet)$ cows. $\uparrow=$ paddock changing for PG cows; aau = arbitrary area units. 
Table 4. Monoterpene content (arbitrary area units $\times 10^{4}$ with SE in parentheses) of milk from strip-grazing (SG) and paddock-grazing (PG) cows

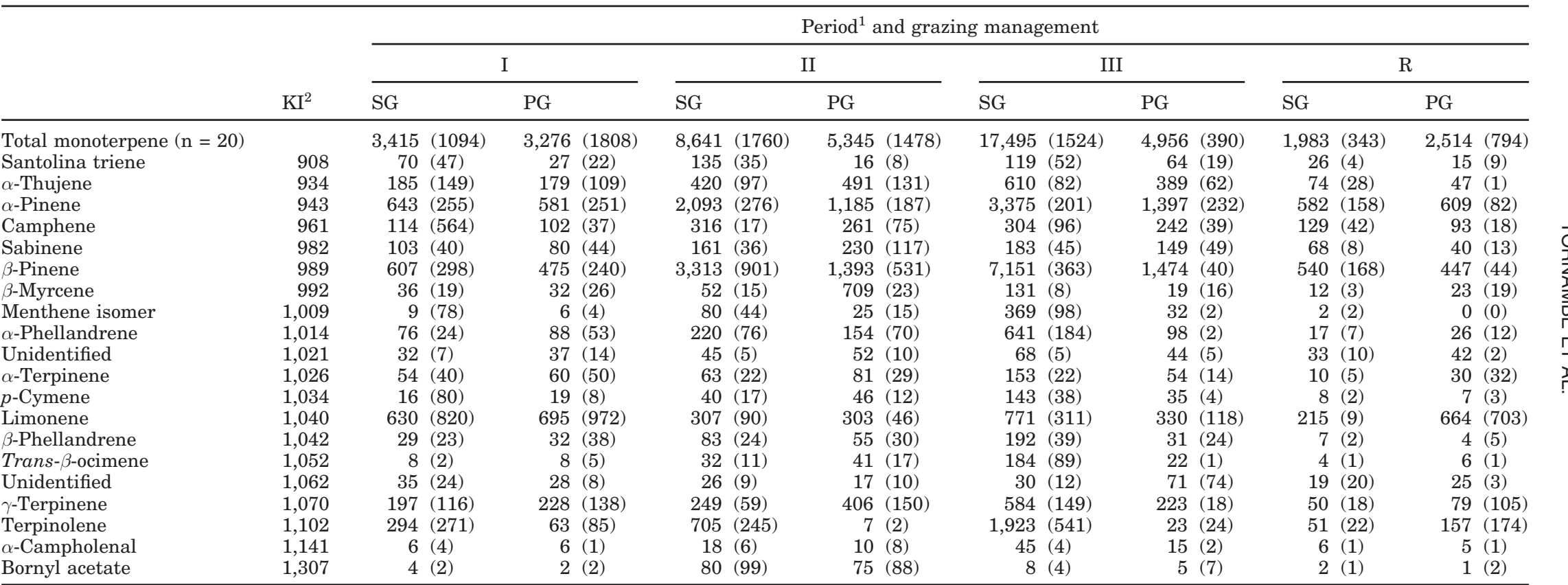

${ }^{1} \mathrm{I}$ = from May 31 to June $13(13 \mathrm{~d}) ; \mathrm{II}=$ from June 13 to June $24(11 \mathrm{~d})$; III = from June 24 to July 1 ( $\left.7 \mathrm{~d}\right)$; R = regrowth period: from October 1 to October 6 ( 5 d). Values reported are the means of $4,3,2$, and 2 analyses in periods I, II, III, and R, respectively.

${ }^{2} \mathrm{KI}=$ Kovats index. 
Table 5. Sesquiterpene content (arbitrary area units $\times 10^{4}$ with SE in parentheses) of milk from strip-grazing (SG) and paddock-grazing (PG) cows

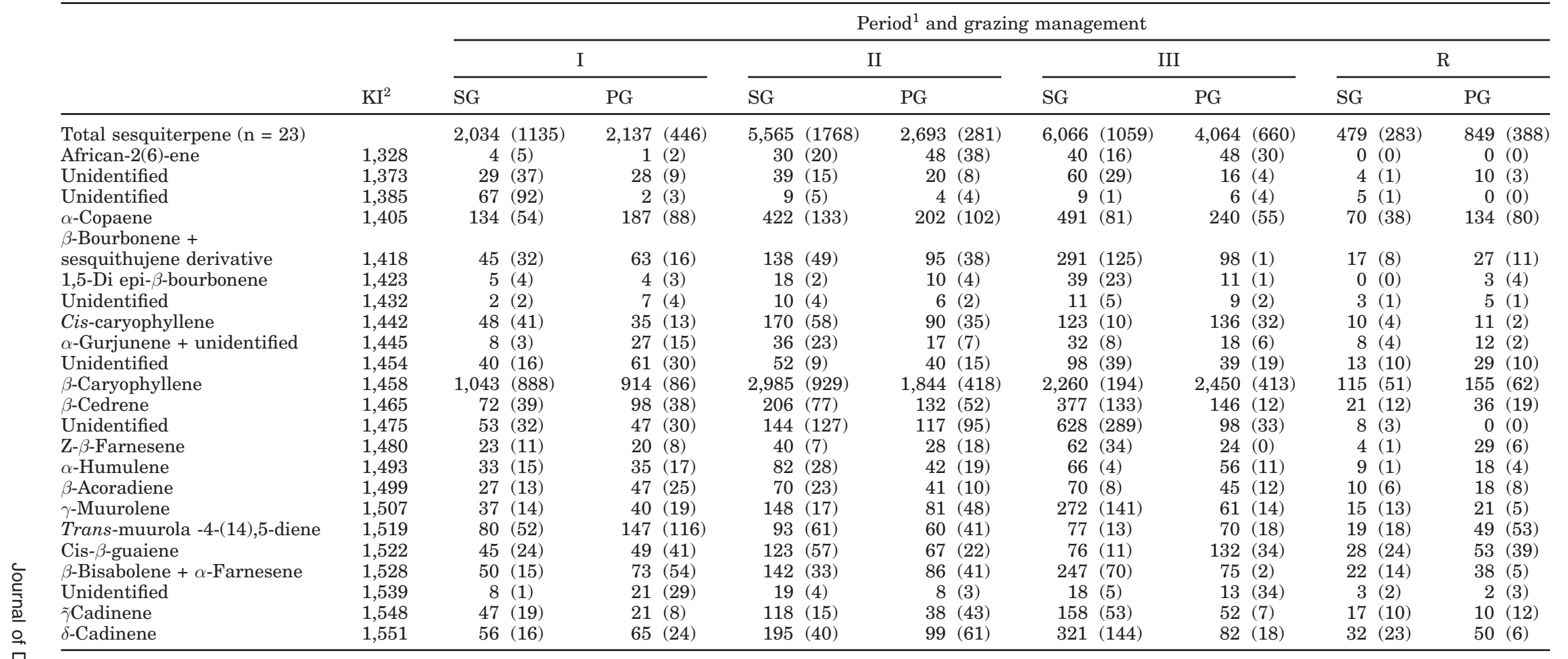

${ }^{1} \mathrm{I}=$ from May 31 to June 13 ( $13 \mathrm{~d}$ ); II = from June 13 to June 24 (11 d); III = from June 24 to July 1 (7 d); R = regrowth period: from October 1 to October 6 (5 d). Values reported are the means of $4,3,2$, and 2 analyses in periods I, II, III, and R, respectively.

${ }^{2} \mathrm{KI}=$ Kovats index 
Table 6. Linear correlations between time spent on the plot in June and milk monoterpenes content (arbitrary area units $\times 10^{4}$ ) according to grazing management $(\mathrm{G})^{1}$

\begin{tabular}{|c|c|c|c|c|c|c|c|c|}
\hline & \multicolumn{3}{|c|}{$P$-values } & \multicolumn{3}{|c|}{ Slopes $^{2}$} & \multirow[b]{2}{*}{$\mathrm{R}^{2}$} & \multirow[b]{2}{*}{$\mathrm{RSD}$} \\
\hline & $\mathrm{G}$ & Period & $\mathrm{G} \times$ Period & Global & SG & PG & & \\
\hline Total monoterpene & NS & $<0.001$ & $<0.001$ & & 558 & 39 & 0.81 & 2224 \\
\hline Santolina triene & 0.001 & NS & & 1.5 & & & 0.55 & 37 \\
\hline$\alpha$-Thujene & NS & $<0.001$ & & 15.0 & & & 0.57 & 132 \\
\hline$\alpha$-Pinene & NS & $<0.001$ & $<0.001$ & & 117 & 30 & 0.90 & 333 \\
\hline Camphene & NS & $<0.001$ & & 8.0 & & & 0.55 & 73 \\
\hline Sabinene & NS & NS & & 2.9 & & & 0.14 & 74 \\
\hline$\beta$-Pinene & 0.03 & $<0.001$ & $<0.001$ & & 270 & 39 & 0.90 & 737 \\
\hline$\beta$-Myrcene & NS & NS & & 1.2 & & & 0.18 & 4 \\
\hline Menthene isomer & NS & $<0.001$ & 0.001 & & 13.8 & 1 & 0.78 & 60 \\
\hline$\alpha$-Phellandrene & 0.04 & $<0.001$ & $<0.001$ & & 22 & 0 & 0.77 & 98 \\
\hline Unidentified & NS & 0.004 & 0.03 & & 1.5 & 0.2 & 0.56 & 10 \\
\hline$\alpha$-Terpinene & NS & NS & & 1.1 & & & 0.08 & 44 \\
\hline$p$-Cymene & NS & $<0.001$ & 0.004 & & 5 & 0.8 & 0.73 & 24 \\
\hline Limonene & NS & NS & & -21 & & & 0.12 & 575 \\
\hline$\beta$-Phellandrene & NS & $<0.001$ & 0.001 & & 7.1 & 0.6 & 0.79 & 31 \\
\hline Trans- $\beta$-ocimene & NS & 0.004 & 0.01 & & 7.1 & 0.7 & 0.64 & 40 \\
\hline Unidentified & NS & NS & & 0.5 & & & 0.03 & 27 \\
\hline$\gamma$-Terpinene & NS & NS & & 6.1 & & & 0.12 & 161 \\
\hline Terpinolene & NS & 0.004 & 0.003 & & 61 & -2 & 0.78 & 330 \\
\hline$\alpha$-Campholenal & NS & $<0.001$ & 0.003 & & 1.5 & 0.4 & 0.81 & 6 \\
\hline Bornyl acetate & NS & NS & & 1.2 & & & 0.05 & 49 \\
\hline
\end{tabular}

${ }^{1} \mathrm{SG}=$ Strip-grazing cows; $\mathrm{PG}=$ paddock-grazing cows.

${ }^{2}$ The slopes are the terpene changes (expressed in arbitrary units) per day spent in the plot. When $\mathrm{G} \times$ Period was significant $(P<0.01)$, the individual slopes for PG and SG milks were given; when $\mathrm{G} \times$ Period was not significant $(P>0.01)$, a Global slope was given.

${ }^{3} \mathrm{RSD}=$ Residual Standard Deviation.

Table 7. Linear correlations between time spent on the plot in June and milk sesquiterpenes content (arbitrary area units $\times 10^{4}$ ) according to the grazing management $(\mathrm{G})^{1}$

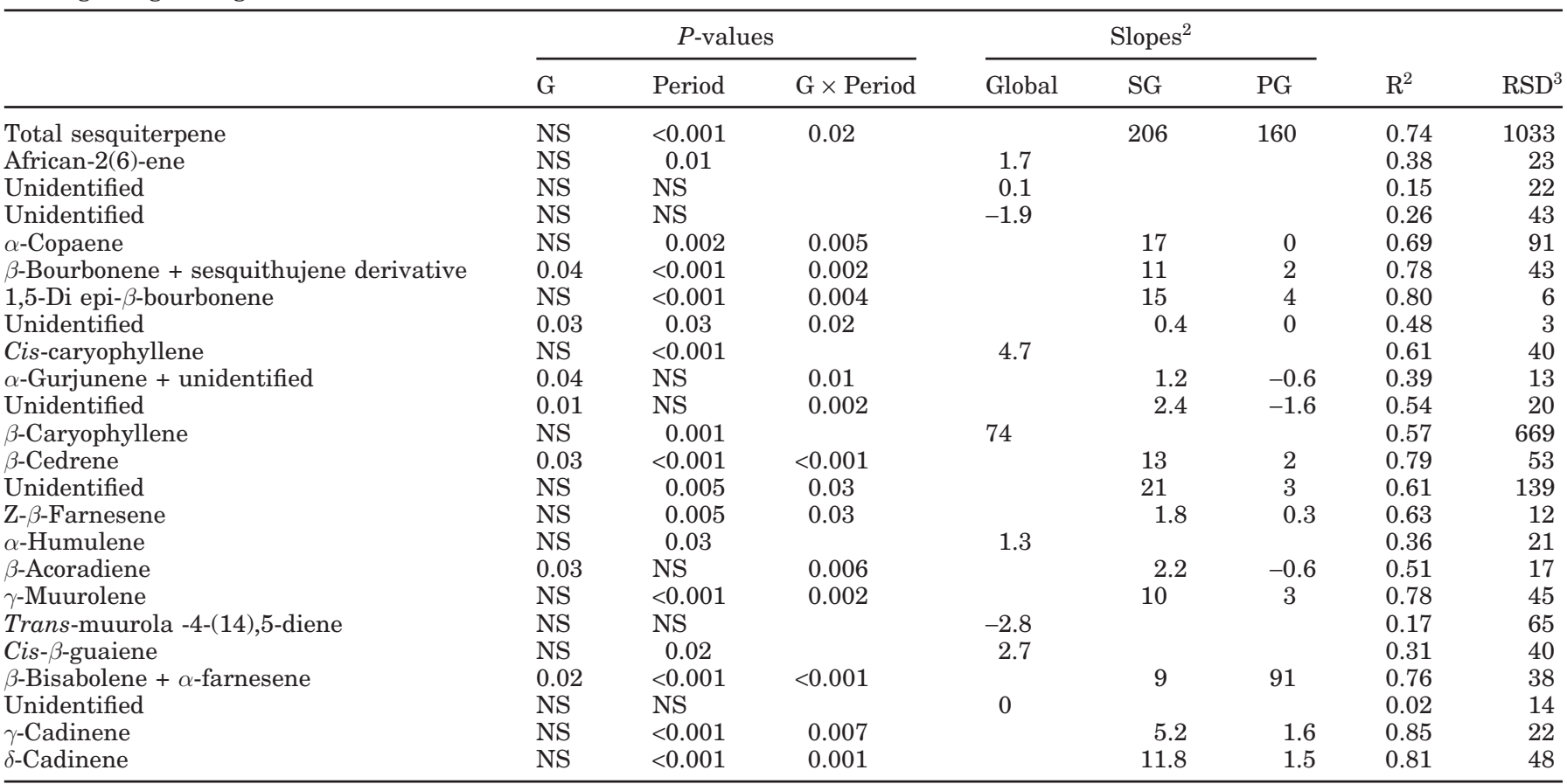

${ }^{1} \mathrm{SG}=$ Strip-grazing cows; $\mathrm{PG}=$ paddock-grazing cows.

${ }^{2}$ The slopes are the terpene changes (expressed in arbitrary units) per day spent in the plot. When $\mathrm{G} \times$ Period was significant $(P<0.01)$, the individual slopes for PG and SG milks were given; when $\mathrm{G} \times$ Period was not significant $(P>0.01)$, a Global slope was given.

${ }^{3} \mathrm{RSD}=$ Residual Standard Deviation. 
and for 17 of the 23 sesquiterpenes found in milks. The most abundant monoterpenes were $\beta$-pinene, $\alpha$-pinene, $\gamma$-terpinene, limonene, $\alpha$-tujene, terpinolene, and $\alpha$ phellandrene. Twelve of the 20 monoterpenes increased significantly in June according to the sampling date and the slope of the correlation was significantly higher in SG than in PG milk for 10 of those 12 monoterpenes (Tables 6 and 7). The average values obtained in period III were between 2 and 41 times the initial value (period I) for SG milks and between 0.4 and 5 times the initial value for PG milks (Tables 4 and 5). Limonene, $\gamma$-terpinene, sabinene, $\alpha$-terpinene, and santolina triene were the main monoterpenes unaffected by the sampling date. For all the monoterpenes, the average values obtained in the regrowth period, $\mathrm{R}$, were lower than or similar to the values observed in period I (Tables 4 and 5).

The most abundant sesquiterpenes were $\beta$-caryophyllene, $\alpha$-copaene, $\beta$-cedrene, transmuurola-4-(14)-5diene, $\beta$-bisabolene, and $\delta$-cadinene. In June, 17 of the 23 sesquiterpenes varied significantly in amount with the time spent on the plot (Tables 6 and 7). As revealed by the interaction and the slopes of the correlation (Tables 6 and 7), the increase with time was significantly higher in SG than in PG milks for 14 sesquiterpenes including the most abundant ones. The average values obtained in period III were between 2 and 12 times the initial value (period I) for SG milks and between 0.6 and 4 times the initial value for PG milks (Tables 4 and 5). For all the sesquiterpenes, the average values obtained in the regrowth period were lower than the average values observed in period I (Tables 4 and 5).

\section{DISCUSSION}

The main result obtained in this trial is a quantification of the milk terpene content variability throughout the grazing season when cows grazed a single plot. The marked increase observed in SG milks against time for the majority of the compounds was well represented by the sum of monoterpenes. Most of the individual compounds varied widely except for limonene, the ubiquity of which is confirmed here (Viallon et al., 1999). Conversely, changes in the sum of sesquiterpene were mainly associated with changes observed for the most abundant sesquiterpenes, such as $\beta$-cariophyllene and $\alpha$-copaene, which represent 45 and $9 \%$, respectively, of the sesquiterpenes. Most of the other sesquiterpenes in milk increased linearly as the forage matured, as did the monoterpenes. When cows were strip grazing through the first pasture growth cycle, the increase in the sum of concentrations of mono and sesquiterpenes in milk with time was apparently due to an actual increase in terpenes and not due to a decline in milk yield because milk yields decreased only about 10 to $15 \%$, whereas the terpene increase was $800 \%$. Increases in milk concentrations were very probably related to the terpene composition of the ingested forage, although this was not analyzed in the current trial (Cornu et al., 2002a,b; Fernandez et al., 2003). In particular, the DM proportion of dicotyledons in the pasture doubled during June. This increase was probably related to the later development of most of the dicotyledon species, including the main aromatic plants providing terpenes in this plot (Thymus pulegioides, A. millefolium, and $M$. athamanticum; Cornu et al., 2001) when compared with most of the abundant Poaceae (Festuca rubra and Agrostis capillaris). Consequently, proportions of dicotyledons in the total forage ingested by the cows probably increased. However, the strong increase in the terpene content of milk may also result partly from the wellknown increase in the terpene content of aromatic plants when they mature and fructify (Gupta, 1996; Sangwan et al., 2001). The very low terpene content in the October milk may be attributed to forage characteristics; forage plants were almost entirely vegetative, including regrowths of dicotyledons that still accounted for $20 \%$ of the biomass. This is also consistent with seasonal variations generally observed in bulk milks (A. Cornu, unpublished data). The decrease in the SG milk $\beta$-cariophyllene in period III is difficult to explain; it may be related to the relative decrease in ingestion of a $\beta$-cariophyllene-rich plant like $A$. millefolium, for example (Cornu et al., 2001).

The lower variability of the milk terpene content observed in PG milk suggests that when the pasture is mature, cows may have chosen the most vegetative parts of the forage (Prache and Peyraud, 2001), thereby selecting high nutritional value but lower concentrations of terpenes. Alternatively, some terpene-rich plants may have been avoided because of their advanced growth stage. In particular, A. millefolium, a major terpene-rich plant of this plot, is known to be eaten when leafy but is not readily consumed when woody. Indeed, the larger surface area allocated to the PG cows and the higher pasture height at the end of the paddock grazing period support the hypothesis that PG cows could choose the ingested forage, unlike the SG cows that had only limited choices among forage plants available.

Another interesting observation that should be confirmed in specifically designed trials is the slight decrease observed in mono- and sesquiterpene content of milk from PG cows during each paddock grazing sequence. At entry to each paddock, cows most likely explored the paddock and first grazed the upper horizon of the cover (Delagarde et al., 2001; Prache and Peyraud, 2001), the richest in flowers and fruits of dicotyle- 
dons and therefore the richest in terpenes. Once the upper parts were consumed, cows probably ate the lower parts, without reproductive parts of dicots, and the poorest in terpenes. However, this remains a hypothesis because we did not clearly observe either a process of grazing down of dicotyledons and Poaceae in the paddocks, or dicotyledon selection in the grazing areas. This slight decrease cannot be attributed to a different proportion of dicotyledons in the different horizons: in the lower (0 to $10 \mathrm{~cm}$ ), intermediate (10 to $22 \mathrm{~cm}$ ), and upper (>22 $\mathrm{cm}$ ) horizons, dicotyledons averaged 26,29 , and $25 \%$ of the total DM biomass, respectively.

In this trial, the very important variability observed in the terpene content of cows fed a single natural diversified upland pasture may be unusual because of the exceptional climatic conditions of the 2003 summer in this area. Average temperature $\left(19.1^{\circ} \mathrm{C}\right)$ and rainfall $\left(43 \mathrm{~mm}\right.$ ) in June were $7.1^{\circ} \mathrm{C}$ higher and $53 \mathrm{~mm}$ lower, respectively than the 35 -yr average. Consequently, some unusual pasture characteristics were observed; a constant biomass and pasture height during June indicating that the growth had stopped, and a very low biomass and pasture height for pasture regrowth. It is also possible that these exceptional climatic conditions enhanced the effect of pasture development stage on herbage terpene content; in dry warm conditions, aromatic plants generally increase their secondary metabolites and essential oil production (Chalchat et al., 1994; Sangwan et al., 2001).

\section{CONCLUSIONS}

Those original results underline the very marked variability in the total content of mono- and sesquiterpenes that may be observed throughout a grazing season when cows are fed a single grassland. Although this trial was carried out during summer 2003, which was exceptionally dry in this area, our results are still of practical interest because they show that the milk terpene content is associated both with botanical composition and with pasture grazing strategy, including management and stage of pasture development. The wide variations in milk terpene content observed in a single plot between periods challenge the reliability of using the terpene fingerprints for purposes such as tracing the origin of the dairy products or the diets of the cows, as has been advocated (Cornu et al., 2002b; Zeppa et al., 2004; Martin et al., 2005). In the latter studies, terpenes were very efficient markers for discriminating among different situations at a given time but their efficacy should be tested over longer periods. In addition, our results confirm that sesquiterpenes seem to be better than monoterpenes as feed markers (Fernan- dez et al., 2003), because their variations in response to plot management factors seem to be lower.

Insofar as the milk terpene content modifies the flavor of dairy products (Coulon et al., 2004), our results raise questions about the consistency of the effect of pasture type on dairy product quality. For example, the specifications of some local cheese productions with "Protected Denomination of Origin" that claim a link to the local vegetation should perhaps include instructions for method of grazing.

With regard to the original results of this trial, it would be useful to confirm our results under more typical climatic conditions and to investigate more thoroughly the possible effects of pasture development stage and grazing management on milk terpene content.

\section{ACKNOWLEDGMENTS}

We thank all the persons who helped in this trial, particularly Isabelle Constant and Olivier Troquier for their technical assistance.

\section{REFERENCES}

Adams, R. P. 2001. Identification of essential oil components by gas chromatography/quadrupole mass spectroscopy. Allure Publishing, Carol Stream, IL.

Andrieu, J., C. Demarquilly, and E. Wegat-Litre. 1981. Tables de prévision de la valeur alimentaire des fourrages. In Prévision de la valeur nutritive des aliments des ruminants. INRA Publications, Route de St-Cyr, Versailles, France.

Bendall, J. G. 2001. Aroma compounds of fresh milk from New Zealand cows fed different diets. J. Agric. Food Chem. 49:4825-4832.

Bosset, J. O., U. Bütikofer, R. Gauch, and R. Sieber. 1994. Caractérisation de fromages d'alpages subalpins suisses: Mise en évidence par GC-MS de terpènes et d'hydrocarbures aliphatiques lors de l'analyse par « Purge and Trap " des arômes volatils de ces fromages. Schweiz. Milchw. Forsch. 23:37-41.

Bugaud, C., A. Bornard, A. Hauwuy, B. Martin, J. C. Salmon, L. Tessier, and S. Buchin. 2000. Relation entre la composition botanique de végétations de montagne et leur composition en composés volatils. Fourrages 162:141-155.

Bugaud, C., S. Buchin, J. B. Coulon, A. Hauwuy, and D. Dupont. 2001. Influence of the nature of alpine pastures on plasmin activity, fatty acid and volatile compound composition of milk. Lait 81:401-414.

Bugaud, C., S. Buchin, A. Hauwuy, and J. B. Coulon. 2002. Texture et flaveur du fromage selon la nature du pâturage: Cas du fromage d'Abondance. INRA Prod. Anim. 15:31-36.

Burt, S. 2004. Essential oils: Their antibacterial properties and potential application in food - A review. Int. J. Food Microbiol. 94:223-253.

Carpino, S., J. Horne, C. Melilli, G. Licita, D. M. Barbano, and P. J. VanSoest. 2004. Contribution of native pasture to sensory properties of Ragusano cheese. J. Dairy Sci. 87:308-315.

Chalchat, J. C., R. P. Garry, and J. Lamy. 1994. Influence of harvest time on yield and composition of Artemisia annua oil produced in France. J. Essent. Oil Res. 6:261-268.

Chalchat, J. C., and A. Michet. 1997. Influence of harvesting time on chemical composition of Mentha piperita L. essential oil. Perfume. Flavor. 22:15-21.

Cornu, A., A. P. Carnat, B. Martin, J. B. Coulon, J. L. Lamaison, and J. L. Berdagué. 2001. Solid phase microextraction of volatile 
components from natural grassland plants. J. Agric. Food Chem. 49:203-209.

Cornu, A., N. Kondjoyan, B. Martin, A. Ferlay, P. Pradel, J. B. Coulon, and J. L. Berdagué. 2002b. Vers une reconnaissance des principaux régimes alimentaires des vaches à l'aide des profils terpéniques du lait. Rencontres Recherches Ruminants, Paris, France 9:370.

Cornu, A., B. Martin, I. Verdier-Metz, and P. Pradel. J. B Coulon, and J. L. Berdague. 2002a. Use of terpene profiles in dairy produce to trace the diet of dairy cows. Proc. 19th General Meeting of the European Grassland Federation, La Rochelle, France 7:550-551.

Coulon, J. B., A. Delacroix-Buchet, B. Martin, and A. Pirisi. 2004. Relation between ruminants management and sensory characteristics of cheeses: A review. Lait 84:221-241.

Deans, S. G., and G. Ritchie. 1978. Antibacterial properties of plant essential oils. Int. J. Food Microbiol. 5:165-180.

Delagarde, R., S. Prache, P. D'Hour, and M. Petit. 2001. Ingestion de l'herbe par les ruminant au paturage. Fourrage 166:189-201.

Dumont, J. P., and J. Adda. 1978. Occurrence of sesquiterpenes in mountain cheese volatiles. J. Agric. Food Chem. 26:364-367.

Dumont, J. P., J. Adda, and P. Rousseaux. 1981. Example de variation de l'arôme à l'interieur d'un même type de fromage: Le Comté. Lebensm. Wiss. Technol. 14:198-202.

Fernandez, C., C. Astier, E. Rock, J. B. Coulon, and J. L. Berdagué. 2003. Characterization of milk by analysis of its terpene fractions. Int. J. Food Sci. Technol. 30:445-451.

Gupta, S. C. 1996. Variation in herbage yield, oil yield and major components of various Ocimum species/variety (chemotypes) harvested at different stage of maturity. J. Essent. Oil Res. 8:275279 .

Hammer, K. A., C. F. Carson, and T. V. Rilevy. 1999. Antimicrobial activity of essential oils and other plant extracts. J. Appl. Microbiol. 86:985-990.

Kondjoyan, N., and J. L. Berdagué. 1996. Compilation of relative retention indices for the analysis of aromatic compounds. Laboratoire Flaveur Publisher, INRA, Clermont-Ferrand, France.

Larsen, T. O. 1999. Volatile flavours production by Penicillium caseifulvum. Int. Dairy J. 8:883-887.
Mariaca, R. G., T. F. H. Berger, R. Gauch, M. I. Imhof, B. Jeangros, and J. O. Bosset. 1997. Occurrence of volatile mono- and sesquiterpenoids in highland and lowland plant species as possible precursors for flavour compounds in milk and dairy products. J. Agric. Food Chem. 45:4423-4434.

Martin, B., A. Cornu, N. Kondjoyan, A. Ferlay, I. Verdier-Metz, P. Pradel, E. Rock, Y. Chillard, J. B. Coulon, and J. L. Berdagué 2005. Milk indicators for recognizing the type of forages eaten by dairy cows. Pages 127-136 in Indicators of milk and beef quality. Wageningen Academy Publishers, Wageningen, The Netherlands.

Moio, L., L. Rillo, A. Ledda, and F. Addeo. 1996. Odorous constituents of ovine milk in relationship to diet. J. Dairy Sci. 79:1322-1331.

NIST/EPA/NIH. 1996. Mass Spectral Database, Standard Reference Database Program of the National Institute of Standards and Technology (NIST). Version 1.5 for PC. www.nist.gov

Prache, S., and J. L. Peyraud 2001. Foraging behaviour and intake in temperate cultivated grassland. Proc. Int. Grassl. Congr. XIX:309-319

Prache, S., A. Cornu, J. L. Berdagué, and A. Priolo. 2005. Traceability of animal feeding diet in the meat and milk of small ruminants. Small Rumin. Res. 59:157-168.

Sangwan, N. S., A. H. A. Farooqi, F. Shabih, and R. S. Sangwan. 2001. Regulation of essential oil production in plants. Plant Growth Regul. 34:3-21.

SAS Institute. 2000. User's Guide: Statistics. Version 8 ed. SAS Inst., Inc., Cary, NC.

Schilchtherle-Cerny, H., M. I. Imhof, E. Fernandez-Garcia, and J. O. Bosset. 2004. Changes in terpene composition from pasture to cheese. Proc. Cheese Art, Ragusa, Italy.

Viallon, C., B. Martin, I. Verdier-Metz, P. Pradel, J. P. Garel, J. B. Coulon, and J. L. Berdagué. 2000. Transfer of monoterpenes and sesquiterpenes from forages into milk fat. Lait 80:635-641.

Viallon, C., I. Verdier-Metz, C. Denoyzer, P. Pradel, J. B. Coulon, and J. L. Berdagué. 1999. Desorbed terpenes and sesquiterpenes from forages and cheeses. J. Dairy Res. 66:319-326.

Zeppa, G., M. Giordano, M. Bertolino, and V. Gerbi. 2004. Use of monoterpenes and sesquiterpenes for the characterization of mountain cheeses. Acta Agric. Slov. 84:17-23. 